\title{
A külföldön élő magyarok jövedelmeinek és folyó átutalásainak elemzése*
}

\author{
Csortos Orsolya - Kóczián Balázs
}

A külföldön dolgozó munkavállalók által belföldre utalt, illetve utalható pénzösszegek a fizetési mérleg több tételében is megjelennek, ami sokszor félreértésekre ad okot, ezért e cikk egyik célja a fogalmak definiálása. A hazautalásokhoz kapcsolódó fogalmak tisztázására és megértésére azért van szükség, mert azok más külső forrásoknál stabilabb külső finanszírozási forrást jelenthetnek egy gazdaság számára, továbbá befolyásolhatják a gazdasági növekedés alakulását, javítják a folyó fizetési mérleg egyenlegét, és ezen keresztül hozzájárulhatnak a kockázati prémium mérséklődéséhez és az ország befektetői megítélésének javulásához is. Miután rámutattunk, hogy milyen gazdasági jelentősége van a külföldi munkavállalói jövedelmeknek és átutalásoknak, ismertetjük, hogy azok miként alakultak az elmúlt években Magyarországon - aminek relevanciájára leginkább a 2016 júniusában az Egyesült Királyságban tartott EU-tagságról szóló népszavazás hívta fel a figyelmet. Bemutatjuk, hogy a külföldön átmenetileg dolgozó magyarok munkajövedelme jelentösen meghaladja a tartósan külföldön élö magyarok folyó átutalásait, és ezek összesen jelentösen javítják a folyó fizetési mérleg egyenlegét. A legtöbb munkabért Németország és Ausztria területén kapják a magyar munkavállalók, míg a tartósan külföldön élő magyarok folyó átutalásaiban Németország mellett az Egyesült Királyság szerepe jelentős. Az Európai Unió országait tekintve a külföldi munkabérek és folyó átutalások nagysága a gazdaság fejlettségével párhuzamosan csökken.

Journal of Economic Literature (JEL) kódok: F24, E01, F43, J61

Kulcsszavak: hazautalások, külföldön dolgozók jövedelmei, külső források, munkaerő-áramlás

\footnotetext{
* Jelen cikk a szerző nézeteit tartalmazza, és nem feltétlenül tükrözi a Magyar Nemzeti Bank hivatalos álláspontját.

Csortos Orsolya a Magyar Nemzeti Bank közgazdasági elemzője. E-mail: csortoso@mnb.hu. Kóczián Balázs a Magyar Nemzeti Bank közgazdasági elemzője. E-mail: koczianb@mnb.hu.

Jelen cikk a szerzők nézeteit tartalmazza, és nem feltétlenül tükrözi a Magyar Nemzeti Bank hivatalos álláspontját. A szerzők köszönetet mondanak a Magyar Nemzeti Bank Makrofinanszírozási és külső egyensúly főosztályán dolgozó kollégáiknak a kutatás során nyújtott segítségükért és az anonim lektoroknak az általuk megfogalmazott konstruktív észrevételekért.
}

A kézirat első változata 2016. december 19-én érkezett szerkesztőségünkbe.

DOI: http://doi.org/10.25201/HSZ.16.2.527 


\section{Bevezetés}

Az Európai Unióhoz való csatlakozást követően - kihasználva a munkaerő szabad áramlásából és a bérszintek között fennálló különbségekből adódó előnyöket - egyre nőtt a külföldön munkát vállaló magyar állampolgárok száma. A külföldön dolgozók számának növekedésével az általuk kapott munkajövedelmek és folyó átutalások értéke is emelkedett. Habár korábban jelent már meg cikk a külföldi munkavállalás jelentőségéről (Bodnár - Szabó 2014) és a hazautalt pénzek mértékéről (Kajdi 2015) is, a külföldi munkajövedelmek és folyó átutalások elmúlt évekbeli alakulása részletesen, országbontásban nem került bemutatásra és elemzésre. Hazánkban legfőképp az Egyesült Királyságban 2016 júniusában tartott EU-s tagságról zajlott népszavazás eredménye hívta fel a figyelmet a jelenség jelentőségére.

Tanulmányunk második fejezetében definiáljuk a hazautalásokhoz kapcsolódó fogalmakat és bemutatjuk a hozzáférhető adatokat és az adatszerzés korlátait. A harmadik fejezet áttekinti, hogy a szakirodalom alapján a külföldi munkavállalói jövedelmeknek és átutalásoknak milyen gazdasági hatásai lehetnek. A negyedik fejezet részletesen elemzi a külföldön dolgozó magyar munkavállalók jövedelmeinek és folyó átutalásainak alakulását. Az ötödik fejezetben nemzetközi kontextusba helyezzük a hazai folyamatokat, végül a hatodik fejezetben összefoglaljuk tanulmányunk főbb tanulságait.

\section{A hazautalásokhoz kapcsolódó fogalmak definiálása}

A külföldön élö és dolgozó munkavállalók által belföldre utalt, illetve utalható pénzösszegek a fizetési mérleg több tételében is megjelennek, ezért a következő fejezetben e fogalmak tisztázására törekszünk. Mielőtt azonban áttekintenénk, hogy hol is jelennek meg a fizetési mérleg statisztikákban a külföldön élő munkavállalóktól érkezett pénzösszegek, tudni kell, hogy a fizetési mérleg a rezidens és nem rezidens háztartások közötti tranzakciókat mutatja be. A fizetési mérlegben a rezidensség megállapításakor nem a szereplő állampolgársága a döntő, hanem az, hogy mely országhoz kötődnek „alapvető gazdasági érdekei” (MNB 2014). Vagyis egy magyar állampolgár lehet rezidens Magyarországon, de akár Németországban is. Leegyszerűsítve egy gazdasági szereplő abban az országban tekinthető rezidensnek, ahol tartósan, életvitelszerűen él. Tartósnak általában az egy éven túli tartózkodás számít, néhány kivételt - pl. a cserediákokat vagy a diplomatákat - leszámítva (IMF 2009). A következőkben rendszerezve mutatjuk be, hogy milyen, a hazautalásokkal összefüggésbe hozható mutatók léteznek; ezek közül először azt a kettőt ismertetjük, amelyek a fizetési mérlegben közvetlenül megfigyelhetők. 


\section{(1) Az átmenetileg külföldön élő munkavállalók munkajövedelmei}

A munkavállalói jövedelmek a fizetési mérleg elsődleges jövedelmei között szerepelnek, és azt mutatják be, hogy a külföldön átmenetileg - egy évnél rövidebb ideig - dolgozó munkavállalók mennyi bruttó munkajövedelmet szereznek. Mivel a fizetési mérleg a rezidens és nem rezidens szereplők közötti tranzakciókat rögzíti, ami az átmeneti külföldi munkavállalás esetén a külföldi munkaadó a magyar munkavállalónak fizetett bérét jelenti - ezért a fizetési mérlegben a bruttó munkabér jelenik meg. Így ez az idősor nem azt mutatja meg, hogy a rezidens szereplők mennyi pénzt utalnak haza, hanem azt, hogy mennyi munkabért kapnak nem rezidens gazdasági szereplőktől. Mivel ugyanakkor ebből a munkabérből a munkavállaló még adót fizet az adott országban ${ }^{1}$ és jövedelmének egy részét megélhetési költségeinek fedezésére fordítja - ami nehezen számszerüsíthető - így a munkavállalói jövedelemnek csak egy részéről feltételezhető, hogy végül ténylegesen hazautalásra kerül. Emiatt félrevezető lenne ezt a mutatót hazautalásnak nevezni, mivel ennek csak egy része kerülhet átutalásra.

\section{(2) A tartósan külföldön élő munkavállalók átutalásai}

A folyó fizetési mérleg másodlagos jövedelmei között megjelenik, hogy a tartósan külföldön élö háztartások mennyi pénzt utalnak haza belföldi háztartásoknak. Amikor egy háztartás tartósan (egy évnél hosszabb időre) külföldre költözik és gazdasági érdeke már a másik országhoz kötődik, nem rezidens szereplővé válik, így ettől kezdve az a tranzakció, amikor külföldi munkaadójától munkabért kap, már nem jelenik meg a hazai fizetési mérleg adataiban (mivel az két nem rezidens szereplő között megy végbe). Ugyanakkor - mivel a külföldön élő hazai háztartás már nem rezidens szereplőnek számít -, amikor ez a háztartás pénzt utal haza egy Magyarországon élő háztartásnak, akkor a tranzakció egy rezidens és egy nem rezidens szereplő között valósul meg, így az megjelenik a fizetési mérleg másodlagos jövedelmei között (amit a fizetési mérleg korábbi módszertana szerint folyó transzfereknek neveztek). A fizetési mérlegnek ez a sora ugyanakkor más tételeket is tartalmaz, amelyről a későbbiekben részletesebben szólunk.

Látható tehát, hogy a folyó fizetési mérleg több tétele is tartalmaz olyan elemeket, amelyeket külföldön élö belföldi származású munkavállalók hazautalhatnának ugyanakkor véleményünk szerint külön-külön egyikre sem, illetve a kettő összegére sem célszerü önmagában hazautalásként hivatkozni. Ahhoz, hogy megértsük és elemezzük, hogy a külföldön élő belföldi származású munkavállalók mekkora pénzösszeget utalnak haza, célszerú újabb fogalmakat definiálni. A pontos fogalomhasználatot az is nehezíti, hogy a nemzetközi statisztika sem egységes e tekintetben, illetve hogy gyakran a külföldi szakirodalomban sem tisztázzák a fenti fogalmakat. Többek között a Világbank is az (1)-es és a (2)-es fogalom összegét nevezi hazauta-

\footnotetext{
${ }^{1}$ Ez a folyó fizetési mérleg másodlagos jövedelmei között szerepel.
} 
lásnak, amit angolul „personal remittances”-nek nevez. Ezzel szemben az Eurostat szóhasználata már pontosabban leírja, hogy az intézmény az elemzések során melyik fogalmat vizsgálja („workers remittances and compensation of employees” - vagyis munkavállalói hazautalások és munkavállalói jövedelmek), amely alatt szintén az (1)-es és (2)-es tételek értendők. Mivel ezen nemzetközi szervezetek mellett számos hazai és nemzetközi szerző is így jár el, célszerú lenne ezt a fogalmat is definiálni. A hazautalásokhoz kapcsolódó fogalmak összefüggéseit az 1. ábra mutatja be.

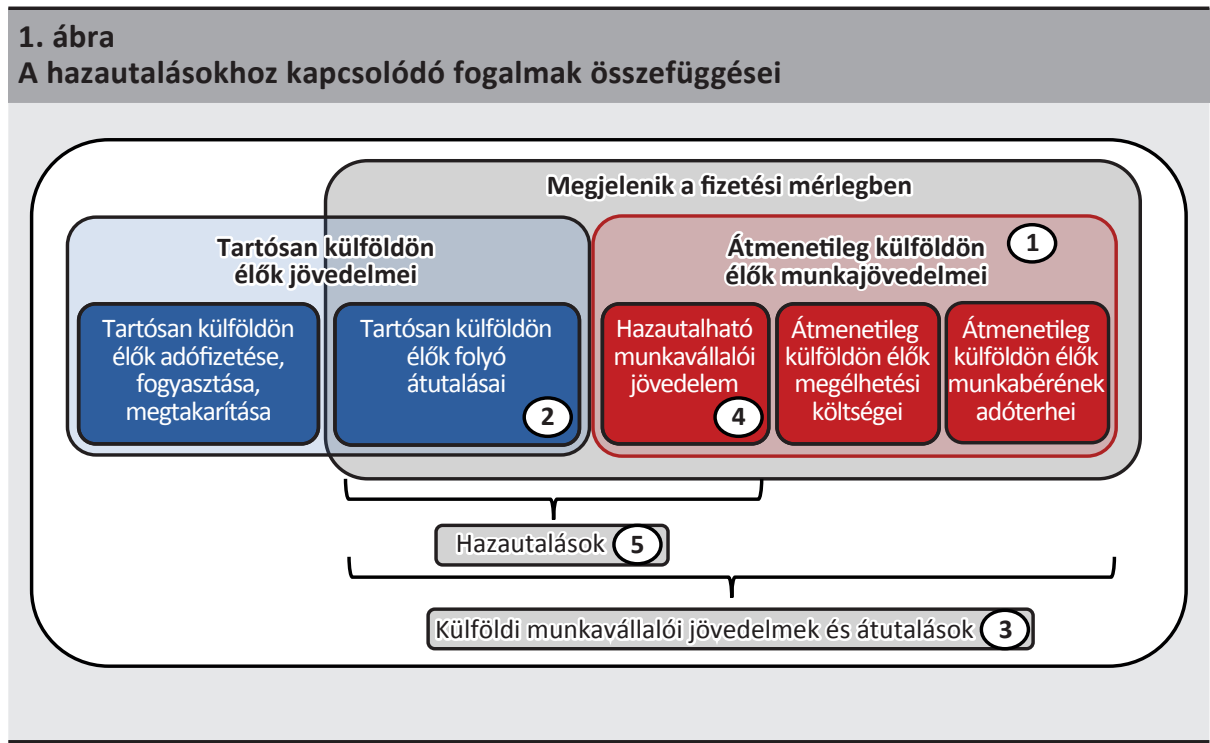

\section{(3) Külföldi munkavállalói jövedelmek és átutalások}

Definíciónk szerint - az Eurostathoz és a Világbankhoz hasonlóan - ez a tétel az átmenetileg külföldön dolgozók munkajövedelmeit és a tartósan külföldön dolgozók átutalásait tartalmazza [(1)+(2)]. Ez a tétel azonban tartalmazza a munkavállalói jövedelmek adóterheit, illetve a jövedelem azon részét, amelyet a gazdasági szereplők megélhetésük fedezésére fordítanak, azaz az (1)+(2) összege végül nem kerül teljes mértékben hazautalásra, így pontatlan lenne az (1)-es és (2)-es tétel összegét hazautalásnak nevezni - annak ellenére, hogy ez sajnos a szakirodalomban vagy a sajtóban is gyakran így szerepel.

\section{(4) Hazautalható munkavállalói jövedelem}

Ez a fogalom az átmenetileg külföldön dolgozók munkajövedelmeinek (1) adókkal, járulékokkal, illetve megélhetési és fogyasztási kiadásokkal csökkentett értékét ta- 
karja. Ezen adatok számszerúsítése azonban több okból is problémás², és meghaladná jelen cikk célkitúzéseit.

\section{(5) Átutalások (2) és hazautalható munkavállalói jövedelmek (4) összege}

Véleményünk szerint ez a fogalom összegzi mindazon tételeket, amelyeket az átmenetileg és tartósan külföldön élő belföldi származású munkavállalók hazautalhatnának - így az egyszerúség kedvéért a cikk további részében a „hazautalások” alatt ezt a fogalmat fogjuk érteni. Definíciónk szerint a hazautalások magukban foglalják egyrészt a tartósan (egy évnél hosszabb ideig) külföldön dolgozó hazai munkavállalók átutalásait, másrészt az átmenetileg (egy évnél rövidebb ideig) külföldön dolgozó munkavállalók adóval csökkentett munkajövedelmének azon részét, amelyet nem fogyasztottak el. Mivel azonban ez utóbbi tételre - ahogy az előző pontban rámutattunk - nincs pontos adat, a hazautalások pontos értéke nehezen számszerúsíthető - ami különösen azért problematikus, mert a legtöbb elemzés a hazautalások ezen tartalmának hatásait vizsgálná meg.

\section{A külföldi munkavállalói jövedelmek és átutalások gazdasági hatásai a szakirodalom alapján}

Jelen fejezet célja, hogy több aspektusból bemutassa a külföldi munkavállalói jövedelmek és folyó átutalások gazdasági hatásait. Itt is szeretnénk hangsúlyozni, hogy a hivatkozott szakirodalmak többsége a „remittances” szóhasználattal él, amelynek az lehet az oka, hogy az általunk is leírt, közgazdaságilag leginkább értelmes hazautalások [(5)] hatásait szeretnék elemezni. Ezzel szemben - ahogy fentebb rámutattunk - a „remittances” alatt leggyakrabban az (1)-es és (2)-es tételek összegét értik, azaz a külföldi munkavállalói jövedelmeket és átutalásokat [(3)]. A konzisztens fogalomhasználat érdekében hivatkozásaink során a kényelmetlen, de pontosabb „külföldi munkavállalói jövedelmek és átutalások" kifejezést használjuk, mivel a szakirodalom többségében az elemzések során a Világbank adataira hivatkoznak, ami az általunk használt ezen kifejezéssel [(3)] áll összhangban. Bár a hazautalások és a külföldi munkavállalói jövedelmek és átutalások fogalmát az elemzések során sokan pontatlanul használják, elmondható, hogy azok gazdasági - jövedelemeloszlásra, jólétre, növekedésre és fizetési mérlegre gyakorolt - hatásai kvalitatívan, irányaiban közel megegyezőek, csupán az egyes változókra gyakorolt hatás mértékében lehetnek érdemi különbségek, mivel a hazautalások a külföldi munkavállalói jövedelmeknek és átutalásoknak egy kisebb részét képezi.

\footnotetext{
${ }^{2}$ Az adók és járulékok a folyó fizetési mérleg másodlagos jövedelmei között jelennek meg. A belföldi rezidensek külföldi fogyasztási kiadásaira ugyan áll rendelkezésre adat, mivel az hazai szolgáltatási importnak tekinthető - ezen belül azonban bizonytalan, hogy annak mekkora részét teszi ki az átmenetileg külföldön dolgozók fogyasztása és mekkorát a külföldre utazó belföldi turisták kiadása.
} 
A Világbank adatai szerint a külföldi munkavállalói jövedelmek és átutalások GDP-arányos értéke jellemzően az ázsiai és afrikai országokban a legmagasabb, míg a Magyarországon tapasztalható érték mérsékeltnek (miközben régiós szinten jelentősnek) mondható (2. ábra). A Világbank adatai szerint a külföldi munkavállalói jövedelmek és átutalások értéke számos ázsiai és afrikai országban meghaladja a GDP 20-30 százalékát, amelynek fényében a szakirodalom jelentős része ezen tranzakciók elemzésekor jellemzően fejlődő, alacsonyabb jövedelmű országokra koncentrált. A közép- és délkelet-európai, illetve balti államokban a külföldi munkavállalói jövedelmek és átutalások GDP-arányos értéke 10 százalék alatti, amelyhez viszonyítva Magyarország 3,3 százalékkal mérsékeltnek mondható, míg a szűken vett közép-kelet-európai régiót kismértékben meghaladja. Mindezeket szem előtt tartva jelen tanulmányban mi a külföldi munkavállalói jövedelmek és átutalások régiós gazdaságokra gyakorolt hatásaira fókuszálunk, miközben önmagában a migrációra, illetve a legszegényebb országokban tapasztalt folyamatokra kevesebb hangsúlyt fektetünk.

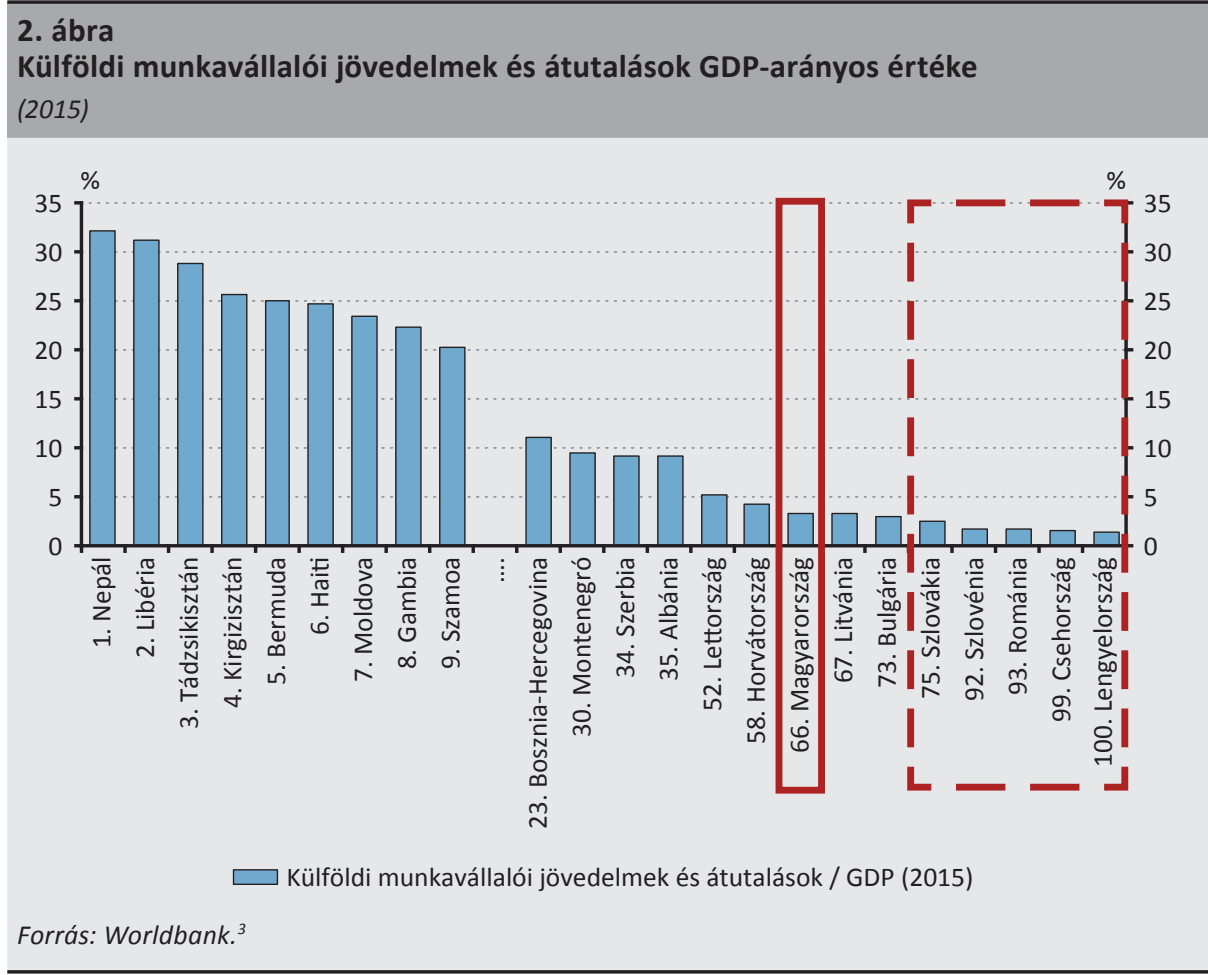

\footnotetext{
${ }^{3} \mathrm{http} / / /$ www.worldbank.org/en/topic/migrationremittancesdiasporaissues/brief/migration-remittances-data.
} 
A külföldi munkavállalói jövedelmek és átutalások hatásait a szakirodalom jellemzően három csoportba sorolja (OECD 2006). Az első csoport a külföldi munkavállalói jövedelmek és átutalások jövedelemelosztásra, a szegénység mérséklésére és az egyéni jólétre gyakorolt, a második a növekedési, foglalkoztatottsági vagy termelékenységi, a harmadik pedig a fizetési mérlegre gyakorolt hatásokat vizsgálja. Ugyanakkor a hatások elemzése során másféle csoportosítás is elképzelhető, például az Európai Parlament egy elemzése (European Parlament 2014) a mikroés makroszintű hatásokat különbözteti meg. Mivel cikkünkben aggregált adatokra támaszkodunk, ezért alapvetően az OECD csoportosításából indulunk ki.

\subsection{Jövedelemelosztásra és jólétre gyakorolt hatások}

A külföldi munkavállalói jövedelmek és átutalások jövedelemelosztásra gyakorolt hatása az empirikus tanulmányok szerint nem egyértelmü, miközben a szegénységhez füződő kockázatokat mérsékelheti. A külföldi munkavállalói jövedelmek és átutalások a társadalmi egyenlőtlenségeket mérő Gini-indexet csökkenhetik ( $A$ hlburg 1996; Taylor 1999), de akár növelhetik is (Adams 1991). A jövedelemelosztásra gyakorolt hatást befolyásolhatja, hogy az ország a migrációs hullám melyik fázisában áll. A migráció kezdeti fázisában jellemzően inkább a vagyonosabb családok vállalhatnak munkát külföldön, így növekedhetnek az egyenlőtlenségek (World Bank 2011; Stark et al. 1988). A migráció későbbi fázisában a szegényebb rétegek is nagyobb mértékben vállalhatnak külföldön munkát, így hosszabb távon az ő külföldi munkajövedelmeik és átutalásaik is mérsékelhetik a társadalmi egyenlőtlenségeket (Stark - Taylor - Yitzhaki 1988). Számos empirikus tanulmány mutat rá arra, hogy a beérkező átutalásokat fogadó háztartásoknak megnövekednek a fogyasztási kiadásai, és alacsonyabb valószínúséggel szegényednek el, mint azok a háztartások, amelyek nem kapnak külföldről pénzösszegeket (Ratha 2013). Emellett a külföldi munkavállalói jövedelmek és átutalások védik a háztartásokat a külső sokkok ellen, és egyfajta társadalombiztosításként is funkcionálnak azokban az országokban, ahol gyakoriak a politikai vagy gazdasági krízishelyzetek (Kapur 2004).

A külföldi munkavállalói jövedelmek és átutalások az oktatási kiadásokra fordítható magasabb jövedelem révén növelhetik a gazdaság és a háztartások jólétét. Vannak olyan tanulmányok, amelyek rámutattak arra, hogy a migráció és a külföldi munkavállalói jövedelmek és átutalások kedvezően hatnak a fogadó ország humántőkéjére (de Haas 2007). Ugyanakkor az is felmerülhet, hogy a magasan képzett munkaerő kivándorlását követően beérkező pénzösszegek nem kompenzálják azt a veszteséget, amelyet a munkaerő kivándorlása jelentett (ún. brain drain) - ennek vizsgálata azonban meghaladja cikkünk célkitǔzéseit. Az IMF (2016) tanulmánya rámutat arra, hogy a CESEE ${ }^{4}$ országokban a kivándorlók képzettsége, iskolázottsága lényegesen magasabb az országra jellemző átlagnál.

\footnotetext{
${ }^{4}$ Albánia, Fehéroroszország, Bosznia és Hercegovina, Bulgária, Horvátország, Csehország, Észtország, Magyarország, Koszovó, Lettország, Litvánia, Macedónia, Moldova, Montenegró, Lengyelország, Románia, Oroszország, Szerbia, Szlovákia, Szlovénia, Törökország, és Ukrajna.
} 
Több tanulmány szerint a külföldi munkavállalói jövedelmeknek és átutalásoknak a pénzügyi-gazdasági jelentőségén túl társadalmi szempontból is érdemi szerepe lehet. Miközben az elemzések többsége a beérkező pénzösszegek monetáris-pénzügyi hatásait vizsgálja, azok nem-anyagi és természetbeni formáinak is legalább akkora jelentősége van. Levitt (1998) tanulmánya rámutatott a migráció kulturális és szociális hatásainak jelentőségére. A nem-anyagi és természetbeni javak „átutalásának” jelentős hatása lehet a társadalom fejlődésére számos olyan területen keresztül, mint például az oktatás, az egészségügy vagy a nemek közötti egyenlőség, illetve a külföldön megszerzett tudás importálása (brain gain).

\subsection{Növekedési hatások}

A külföldi munkavállalói jövedelmek és átutalások több csatornán keresztül is élénkithetik a gazdasági növekedést. Számos tanulmány bemutatta, hogy a külföldi munkavállalói jövedelmek és átutalások folyamatos beáramlása mérsékli a kibocsátás volatilitását (IMF 2005; World Bank 2006; Chami et al. 2008), emellett több empirikus elemzés arra jutott, hogy pozitivan hatnak a fogadó ország gazdasági növekedésére (Solimano 2003, World Bank 2006); ugyanakkor többen azt hangsúlyozzák, hogy a növekedésre gyakorolt hatása számos tényezőtől függ (pl. annak felhasználásától). A külföldi munkavállalói jövedelmek és átutalások ösztönzőleg hatnak a fogyasztásra és beruházásra, ezáltal mérsékelhetik a recesszió mértékét és segíthetik a fogadó ország gazdaságának fellendülését. Emellett a fogyasztásra vagy beruházásra való felhasználásnak kedvező közvetett, másodkörös vagy tovagyürüző (multiplier) hatásai is vannak. llyen tovagyűrúző hatás például, hogy a kiskereskedelmi forgalom bővülése növeli a keresletet, és végső soron a kibocsátást és a foglalkoztatottságot is (Lowell - de la Garza 2000; Ratha 2003). A közvetett hatások azáltal is érvényesülhetnek, hogy a beérkező külföldi munkavállalói jövedelmek és átutalások forrásokat szabadítanak fel, amelyek aztán beruházásokra használhatóak fel, ami pozitivan hat a foglalkoztatottságra és a növekedésre is. Léon-Ledesma - Piracha (2001) becslései szerint 11 közép-kelet-európai országban a külföldi munkavállalói jövedelmek és átutalások szignifikánsan növelik a gazdaság beruházásokra fordítható forrásait.

Ugyanakkor a külföldi munkavállalói jövedelmeknek és átutalásoknak kedvezőtlen növekedési hatásai is lehetnek. A foglalkoztatottságra, inflációra és importra gyakorolt hatások attól függnek, hogy a beérkező külföldi munkavállalói jövedelmek és átutalások következtében megnövekvő keresletre a gazdaság kínálati oldala menynyire rugalmasan tud reagálni. Ha például a kínálat nem képes megfelelően alkalmazkodni a megnövekedett kereslethez, annak inflációs hatásai lehetnek (Adams 1991; Barajas et al. 2011; El-Sakka 1999). Magas a valószínúsége, hogy a beérkező pénzösszegeket a fogadó háztartások fogyasztási (jellemzően importált) javakra költik belföldi beruházások megvalósítása vagy megtakarítások felhalmozása helyett. Ezzel összhangban többen arra jutottak (Alper - Neyapti 2006; de Haas 2007), hogy a külföldi munkavállalói jövedelmek és átutalások csak hosszabb távon ösztönöz- 
hetik a beruházásokat és a gazdasági növekedést. Emellett a külföldi munkavállalói jövedelmek és átutalások beérkezése és az azokra való állandó ráutaltság csökkentheti a munkapiaci részvételt és a munkaórák számát (Buch et al. 2002; Chami et al. 2003). Az inaktivitás emelkedése növelheti a bérszínvonalat is, illetve a pénzek beáramlása a reálárfolyam erősödését okozhatja (Chami et al. 2008; Bourdet - Falck, 2006; Barajas et al. 2011). Az IMF (2016) bemutatja, hogy a külföldi munkavállalói jövedelmek és átutalások beáramlása a rezervációs bérek emelésén keresztül szignifikánsan növeli a munkapiaci inaktivitást. Szélsőséges esetben viszont a beérkező pénzektôl való függőség egy sajátos fertőzési csatornát is jelenthet: ha a pénzeket küldő országban válság következik be, az a fogadó országokra kedvezőtlenül hathat (Alvarez-Tinajera 2010).

A külföldi munkavállalói jövedelmek és átutalások a pénzügyi mélyülésen keresztül kedvezően hathatnak a gazdasági kilátásokra. Az IMF (2016) számításai szerint azokban az országokban, ahol magas a külföldi munkavállalói jövedelmekre és átutalásokra való ráutaltság (a hazautalások GDP-arányos értéke meghaladja a 10 százalékot), azok támogathatják a pénzügyi rendszer mélyülését - amelyet általában a magánszektor GDP-arányos hiteleivel, illetve betéteivel mérnek. A beérkező pénzösszegeknek köszönhetően ugyanis nőhet a magánszektor banki betétállománya és így a nyújtott hitelállomány, amely végül ösztönzően hathat a beruházásokra ( $A g$ garwal et al. 2006; Giuliano and Ruiz-Arranz 2005, 2009; Gupta et al. 2009; Ratha 2013). A külföldi munkavállalói jövedelmek és átutalások beérkezése lehetővé teheti pénzügyi és nem pénzügyi eszközök felhalmozását, ezáltal javítva a hozzáférést a pénzügyi szolgáltatásokhoz és beruházási lehetőségekhez (Orozco et al. 2005; IMF 2005). Yasseen (2012) bemutatja, hogy a feltörekvő országokban pozitív kapcsolat van a külföldi munkavállalói jövedelmek és átutalások és a pénzügyi rendszer fejlettsége között. Ugyanakkor ezek a kedvező hatások a kivándorlás állandósulásával vagy növekedésével mérséklődhetnek.

Mindezek fényében a külföldi munkavállalói jövedelmek és átutalások és a gazdasági növekedés közötti kapcsolat nem egyértelmü, és a potenciálisan kedvezö hatások önmagukban nem jelenthetnek csodaszert és nem helyettesithetik a megfelelö gazdaságpolitikát egy ország számára (Stratan et al. 2013). A megfelelő gazdaságpolitika és fejlesztési stratégiák támogathatják leginkább azt, hogy a fejlődő országokba érkező külföldi munkavállalói jövedelmek és átutalások pozitív növekedési hatással bírjanak. Emellett a kivándorlásnak és a külföldi munkavállalói jövedelmekre és átutalásokra való ráutaltság kedvezőtlen hatásai mérsékelhetőek olyan gazdaságpolitikai intézkedésekkel, amelyek olyan gazdasági-intézményi környezetet teremtenek, amely nem ösztönöz további kivándorlásra, vagy támogatja a már kivándorlottak visszatérését; az országban maradtakat aktívabb munkapiaci részvételre ösztönzi; illetve támogatja, hogy a beérkező pénzösszegeket fogyasztás helyett beruházásokra fordítsák (IMF 2016). 


\subsection{A fizetési mérlegre gyakorolt hatás}

A külföldi munkavállalói jövedelmek és átutalások kedvezően érintik a folyó fizetési mérleget, és támogatják a hosszú távon fenntartható pálya elérését. Az a tény, hogy a külföldi munkavállalói jövedelmek és átutalások stabilabb forrásnak bizonyulnak, és kevésbé ciklikusan viselkednek más külső forrásokhoz (pl. nemzetközi segélyek, FDI, hitelek) képest (részletesebben lásd később), a fizetési mérlegre és annak fenntarthatóságára számos kedvező következménnyel bírnak (IMF 2005; Ratha et al. 2009). A külföldi munkavállalói jövedelmek és átutalások előnye, hogy felhasználásukat például nem kötik magas importtartalmú beruházási projektek megvalósításához, nem kell őket visszafizetni és nincs rajtuk kamat. A kutatások többsége emellett azt hangsúlyozza, hogy a megnövekedett importigény a gazdasági fejlődés, a fogyasztási és beruházási javak termelésében bekövetkező strukturális változások vagy a nemzetközi munkamegosztás változásának a következménye (Glytsos 1993; Straubhaar 1988).

A külföldi munkavállalói jövedelmek és átutalások stabilitása hozzájárul a fogadó ország gazdasági stabilitásához is. A nyitott gazdaságok számára fontos a folyó fizetési mérleg olyan szinten tartása, hogy az ne veszélyeztesse a külső adósság fenntarthatóságát (Holmes 2006). Buch és Kuckulenz (2010) $)^{5}$ bemutatta, hogy a külföldi munkavállalói jövedelmek és átutalások, azáltal, hogy pozitívan hatnak a folyó fizetési mérlegre, a külső tartozások csökkentésének eredményeként mérséklik az ország kockázati prémiumát és javítják befektetői megítélését; ezek pedig végül kedvezőbb finanszírozási feltételekhez vezetnek, támogatva a beruházásokat és a gazdasági növekedést is. Hassan és Holmes (2015) rámutatott, hogy magasabb külföldi munkavállalói jövedelmek és átutalások mellett a folyó fizetési mérleget érő sokkok kevésbé perzisztensek, és gyorsabb alkalmazkodás követi őket. Továbbá Bugamelli és Paternó (2009) rámutatott arra, hogy a hazautalások csökkentik a folyó fizetési mérleg válságok, és így a pénzügyi válságok bekövetkezésének valószínűségét. Mindezekkel szemben egyes tanulmányok arra mutattak rá, hogy a beérkező pénzösszegek a fogadóországban felhajtják az ingatlanárakat, ami a források félreallokáltságához vezethet és kockázatot jelenthet a pénzügyi stabilitásra is (Stepanyan - Poghosyan - Bibolov 2010).

\section{A munkavállalói jövedelmek és folyó átutalások alakulása Magyarországon}

Mint azt eddig bemutattuk, a külföldi munkavállalói jövedelmeknek és átutalásoknak szerteágazó makrogazdasági hatásai lehetnek, ezért indokoltnak tartjuk hazai alakulásukat részletesen is megvizsgálni. Ahogy a második fejezetben bemutattuk, a két tétel összegét félrevezető lenne hazautalásnak nevezni, mivel az átmenetileg

\footnotetext{
${ }^{5}$ Hozzájuk hasonlóan több empirikus tanulmány hangsúlyozza, hogy a hazautalások mérséklik a folyó fizetési mérleg hiányát (Buch et al. 2002; Buch-Kuckulenz 2004; Nayyar 1994).
} 
külföldön dolgozó munkavállalók bruttó keresetüknek csak egy részét utalhatják ténylegesen Magyarországra, ugyanis a külföldön élő munkavállaló jövedelmének többi részéből adót fizet, illetve megélhetési költségeit fedezi ${ }^{6}$. Jelen fejezetnek és cikknek nem célja, hogy becslést adjon a külföldön élő magyar munkavállalók hazautalásainak értékére; arra törekszünk, hogy képet adjunk a fizetési mérlegben megtalálható adatokról, azaz az átmenetileg külföldön dolgozó magyar munkavállalók munkabérének [fenti felsorolásunkban (1)], illetve a tartósan külföldön élő magyarok átutalásainak (2) alakulásáról. A következő fejezetben ezeket a tételeket mutatjuk be részletesen.

\subsection{Milyen adatok között találhatók külföldi munkavállalóktól származó jövedelmek vagy átutalások?}

A külföldön átmenetileg dolgozó munkavállalók jövedelme a jövedelemegyenlegben (az elödleges jövedelmek között) jelenik meg, és egyenlege az elmúlt években egyre nagyobb mértékben csökkentette a jövedelemegyenleg hiányát. Az átmenetileg külföldön munkát vállalók (adókat is tartalmazó) bruttó jövedelme a jövedelemegyen-

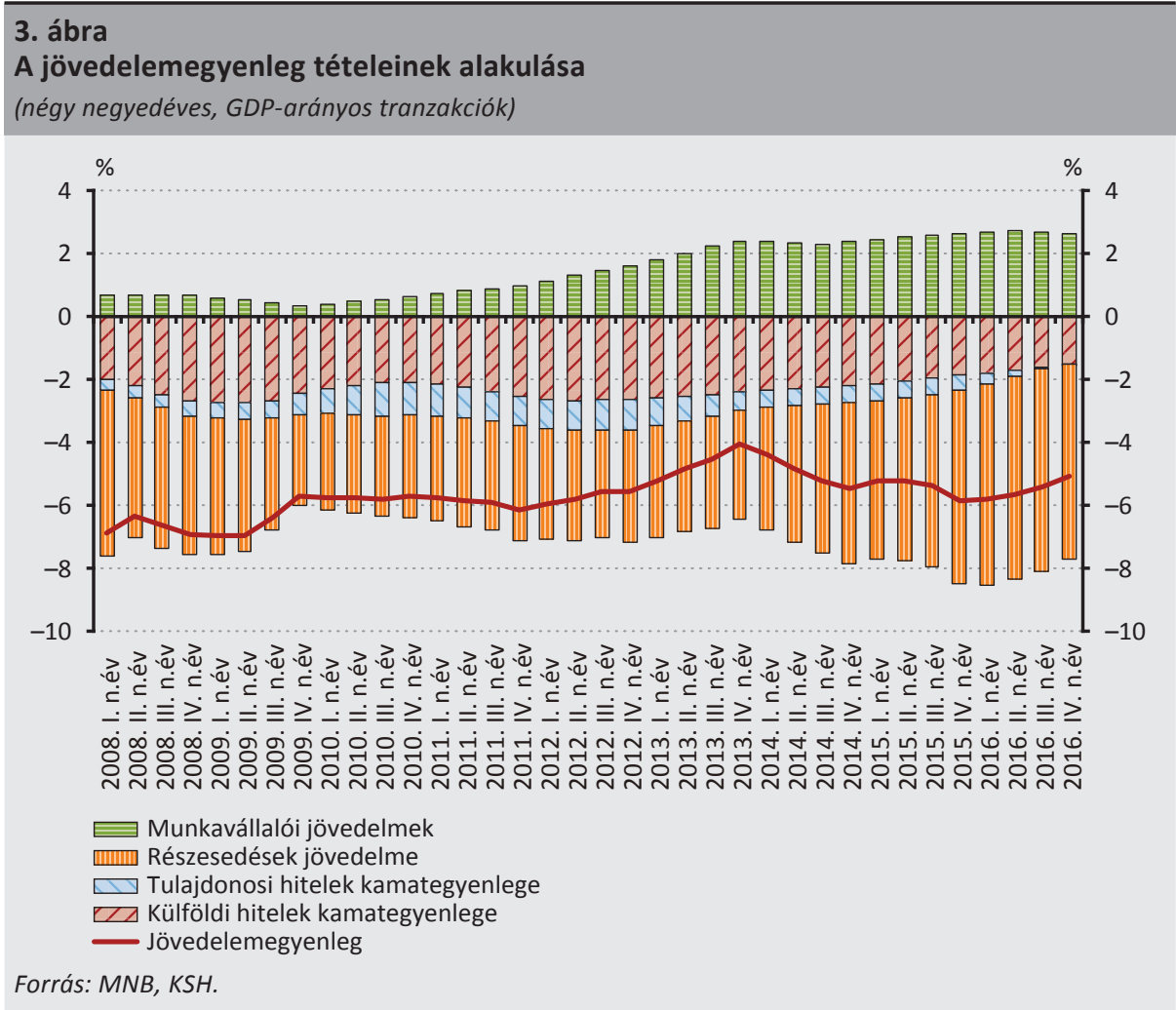

${ }^{6}$ Érdemes lehet ugyanakkor megjegyezni, hogy ez a két tétel is szerepel a fizetési mérleg adataiban, mivel az adófizetés a transzferek között - a külföldön például fogyasztásra elköltött jövedelem az import értékében -, míg a jövedelem megtakarított része a pénzügyi eszközök bővülésében jelenik meg. 
legben szerepel. Ennek egyenlege (vagyis a bevételi és kiadási értékek különbsége) az utóbbi negyedévekben a GDP közel 3 százalékával mérsékelte a jövedelemegyenleg hiányát és növelte a folyó fizetési mérleg többletét (3. ábra). Ennek ellenére a jövedelemegyenleg hiánya a GDP mintegy 5-6 százalékát tette ki, mivel a külföldi tulajdonú vállalatok nyeresége és a külföldi hitelekre fizetett kamatok értéke ezt a tételt jelentősen meghaladta.

A tartósan külföldön élök folyó átutalásai a folyó fizetési mérleg másodlagos jövedelmei között szerepelnek. A tartósan külföldön dolgozó munkavállalók a korábbiakban részletezett okok miatt nem rezidensnek minősülnek. A külföldiek (nem rezidensek) belföldi szereplők számára történő viszonzatlan átutalásai (transzferei) a másodlagos jövedelmeken belül, az egyéb folyó- és tőketranszferek között kerülnek elszámolásra. Ezt az MNB elemzéseihez hasonlóan az egyéb elsődleges jövedelmekkel, valamint a tőkemérleg tételeivel együtt transzferegyenlegnek nevezzük (4. ábra). Az egyéb folyó transzferek között ugyanakkor más tételek is szerepelnek: például az átmenetileg külföldön dolgozók munkabére után, az idegen ország szá-

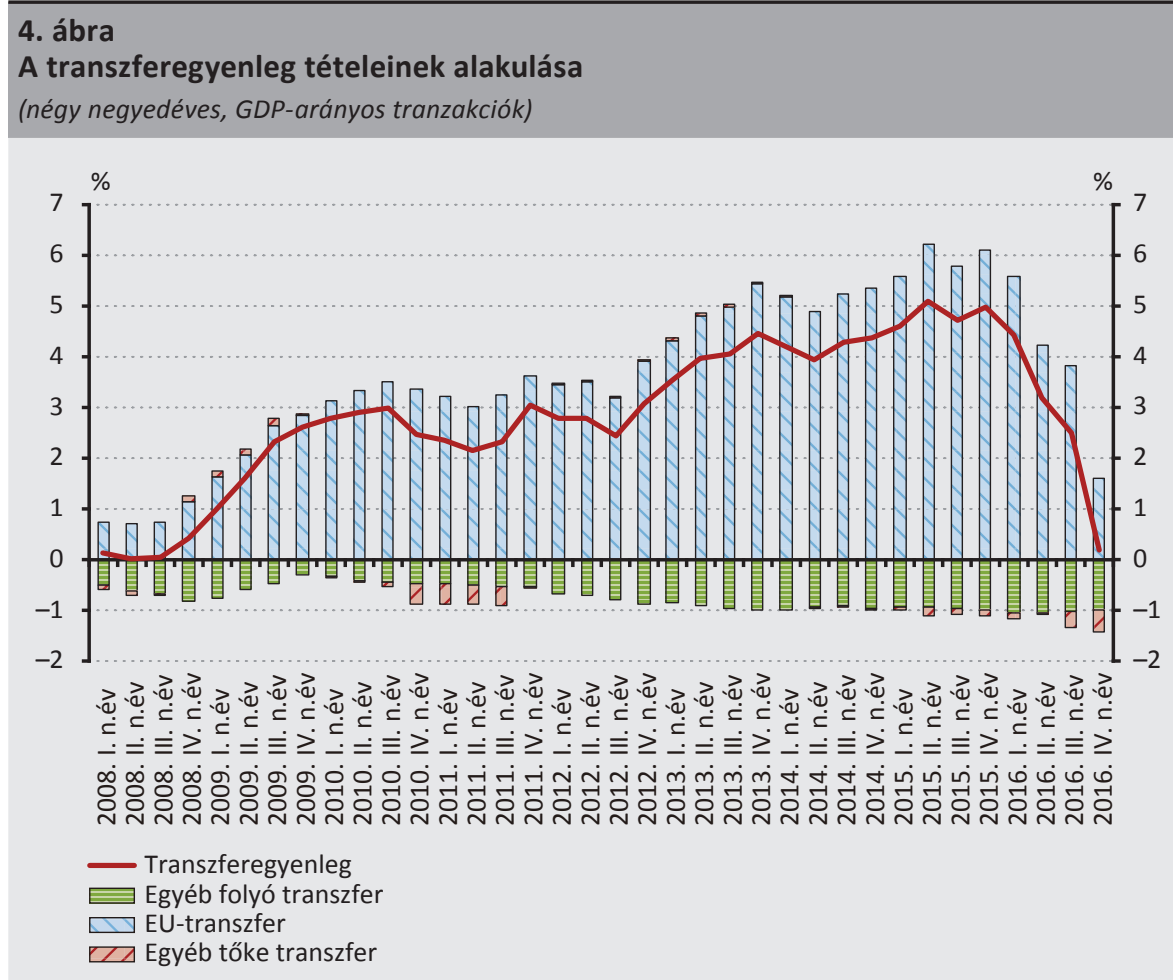

Megjegyzés: A tartósan külföldön élő munkavállalók átutalásai az egyéb folyó transzferek között jelennek meg.

Forrás: $M N B, K S H$. 
mára befizetett adó is. Így az, hogy összességében az EU-transzfereken kívüli egyéb folyó transzferek egyenlege nettó kifizetést mutat, azt jelenti, hogy az átmenetileg külföldön dolgozók külföldre fizetett adója meghaladja a tartósan külföldön élók átutalásait. A tartósan külföldön élők átutalásai ugyanakkor más adatszolgáltatóktól (pl. Eurostat - amely a nemzeti statisztikai szervek által számára átadott adatokat publikálja) megismerhetőek, ami alapján az elmúlt években értékük a GDP 0,5 százaléka közelében alakult, és így érdemben elmaradt az átmenetileg külföldön dolgozók munkabérétől. A transzferegyenleg többletének alakulása szempontjából az EU-transzferek felhasználása a meghatározó.

Érdemes megjegyezni, hogy míg eddig a fizetési mérlegből származó adatokra támaszkodtunk, addig a továbbiakban az Eurostaton (a fizetési mérleg adatai között) megtalálható, külföldi munkavállalói jövedelmekre és átutalásokra vonatkozó adatokat fogjuk bemutatni, amelyen belül a tényleges hazautalásokat részben tartalmazó munkavállalói jövedelmek mellett a tartósan külföldön élők átutalásait is áttekintjük. Az Eurostaton ugyanis részletesen - országbontásban - is elemezhetők a külföldi munkavállalói jövedelmekre és átutalásokra vonatkozó adatok.

\subsection{A munkavállalói jövedelmek}

Az átmenetileg külföldön dolgozó magyarok munkabére a válságot követöen - részben a növekvő munkanélküliség miatt - csökkent, azonban a növekedés stabilizálódásával, valamint az uniós munkavállalásra vonatkozó utolsó szabályok oldódásával összhangban fokozatosan emelkedett. Az átmeneti külföldi munkavállalásból származó jövedelmek értéke a válság előtt mintegy 1,2-1,5 milliárd euro közelében alakult, majd 2009-ben érdemben visszaesett. Ebben jelentős szerepe lehetett annak, hogy a környező országokat is érintette a válság, az emelkedő munkanélküliség pedig feltehetően súlyosabban érintette a külföldi munkavállalókat (ami alátámasztja azt az elméleti fejezetben is kifejtett hipotézist, hogy a hazautalások fertőzési csatornát is jelenthetnek). Ugyanakkor ebben az esetben érdemes megjegyezni, hogy Magyarországon a válságot követően a külföldi források beáramlása - ezalatt az adósság jellegű forrásokat és a nettó közvetlentőke-befektetések beáramlását értve - jóval nagyobb visszaesést mutatott, vagyis - mint arra szintén az elméleti fejezetben utaltunk - a külföldi munkabérek ennél kisebb mértékben csökkentek: tehát stabilabb forrást biztosítottak a gazdaság szereplői számára. A külföldi munkabérek ezt követően fokozatos emelkedést mutatnak, és 2013-ra már közel 3 milliárd eurót értek el, aminek - mint azt korábban kifejtettük - csak egy része kerülhet ténylegesen hazautalásra. A bővülés főként 2010-et követően indult meg, és - mint azt az országbontást tartalmazó adatoknál látni fogjuk - Németországot érintette a legnagyobb mértékben. Ebben annak is jelentős szerepe volt, hogy a Németországra vonatkozó, magyar munkavállalókat érintő utolsó korlátozások 2011 elején oldódtak fel. A Magyarországon átmenetileg munkát vállaló külföldiek munkabérét is figyelembe véve így 2013 és 2016 között a munkavállalói jövedelmek 2,5-3 milliárd 
euróval növelték a folyó fizetési mérleg egyenlegét - ami azonban az adófizetést és megélhetési költségeket is tartalmazza.

Az átmeneti külföldi munkavállalás szempontjából a legfontosabb célország a magyar munkavállalók számára Németország és Ausztria (5. ábra). Az átmeneti külföldi munkavállalás alatt jellemzően ingázást vagy idénymunkákat lehet elképzelni. Ezt - valamint az országok közötti bérszinteket - figyelembe véve nem meglepő, hogy az átmeneti külföldi munkavállalás tekintetében a külföldi munkabérek legnagyobb része Ausztriából származik, míg második helyen - a földrajzilag távolabbi, de még elérhető közelségben lévő és Magyarországról jól megközelíthető fekvéssel rendelkező - Németország szerepel. Ez összhangban van a Statisztikai Szemlében megjelent, a munkaerő-felmérésből származó adattokkal (Lakatos 2015). 2016-ban az összesen közel 3,5 milliárd eurót kitevő külföldi munkabér mintegy háromnegyede ebből a két országból származott. Érdemes megjegyezni azt is, hogy a Magyarországon átmenetileg dolgozó külföldi (nem rezidens) munkavállalók munkabére közel 500 millió eurót tett ki. Az átmenetileg Magyarországon dolgozók leggyakrabban a szomszédos országokból, főként Romániából és Szlovákiából érkeznek. Ennek hátterében vélhetően az ezen országokban élő, jellemzően magyar anyanyelvű munkavállalók állnak.

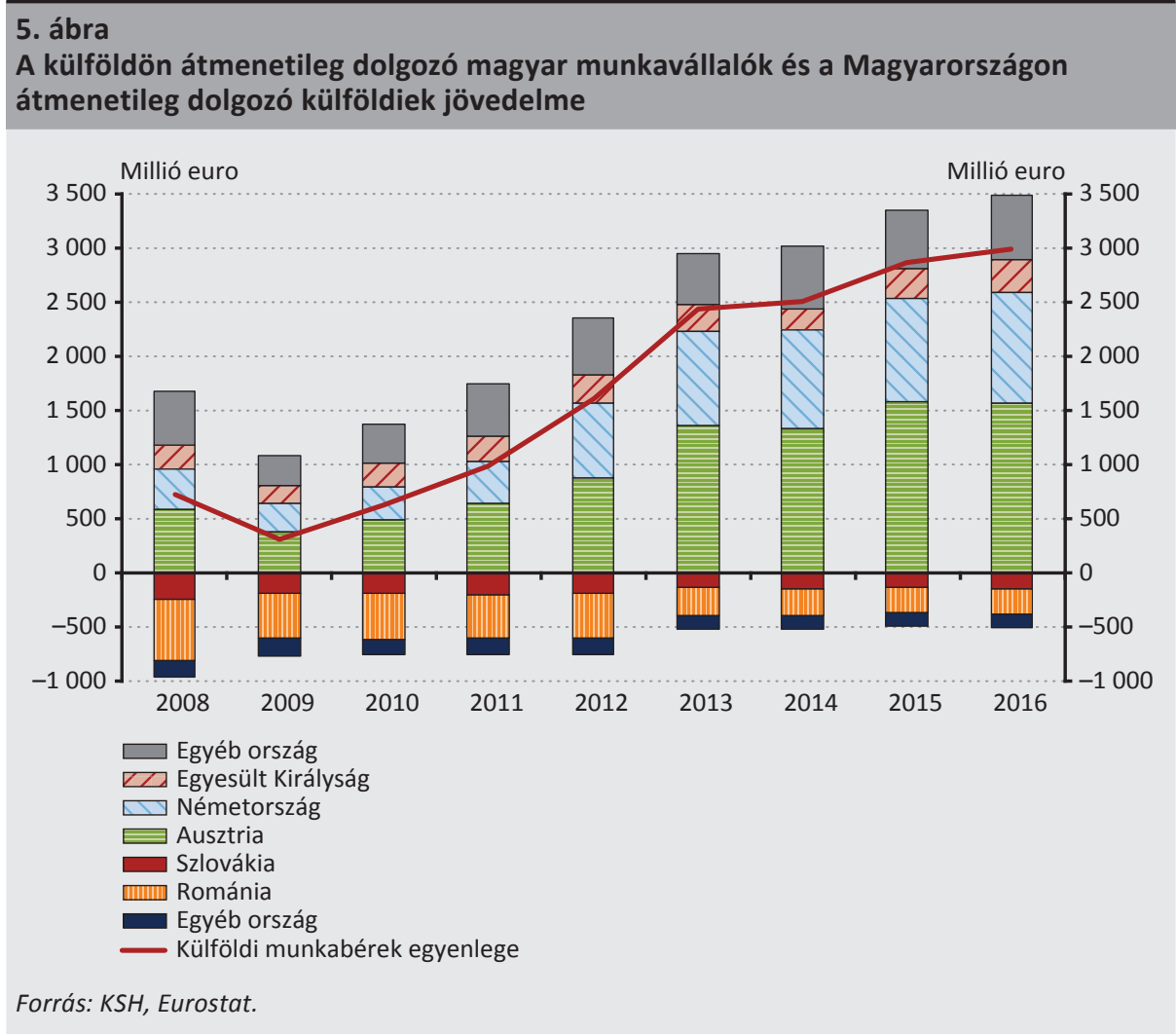




\subsection{A tartósan külföldön élők folyó átutalásai}

A tartós külföldi munkavállalás mellett megvalósuló folyó átutalás jelentős mértékben csak a válságot követő években emelkedett meg, ami feltehetőleg azzal áll öszszefüggésben, hogy tartósan a válságot követö recesszió miatt költözhettek külföldre nagyobb számban magyar munkavállalók. A folyó átutalások értéke a fokozatos emelkedést követöen 2016-ra mintegy 700 millió euróra emelkedett - vagyis jóval kisebb összeget tesz ki, mint a külföldi munkavállalók munkajövedelme, azonban ez az összeg teljes mértékben hazautalásra került. A tartós külföldi munkavállalással összefüggésben a folyó átutalások értéke 2008-at megelőzően nem volt jelentős, és 100 millió euro alatt maradt. Ugyanakkor a válságot követően - vélhetően a munkanélküliség magyarországi emelkedésének következményeképpen - jelentősen nőtt a tartósan külföldön dolgozó magyarok által hazautalt pénzek összege. Ennek hátterében szerepe lehetett annak is, hogy a magyar munkavállalókat érintő utolsó korlátozások 2011-ben oldódtak fel, így például a Németországból hazautalt jövedelmek is ezt követően indultak növekedésnek.

A tartósan külföldön dolgozók folyó átutalásainak legnagyobb része 2012-töl Németországból érkezett, a második helyen pedig az Egyesült Királyság áll (6. ábra). A folyó

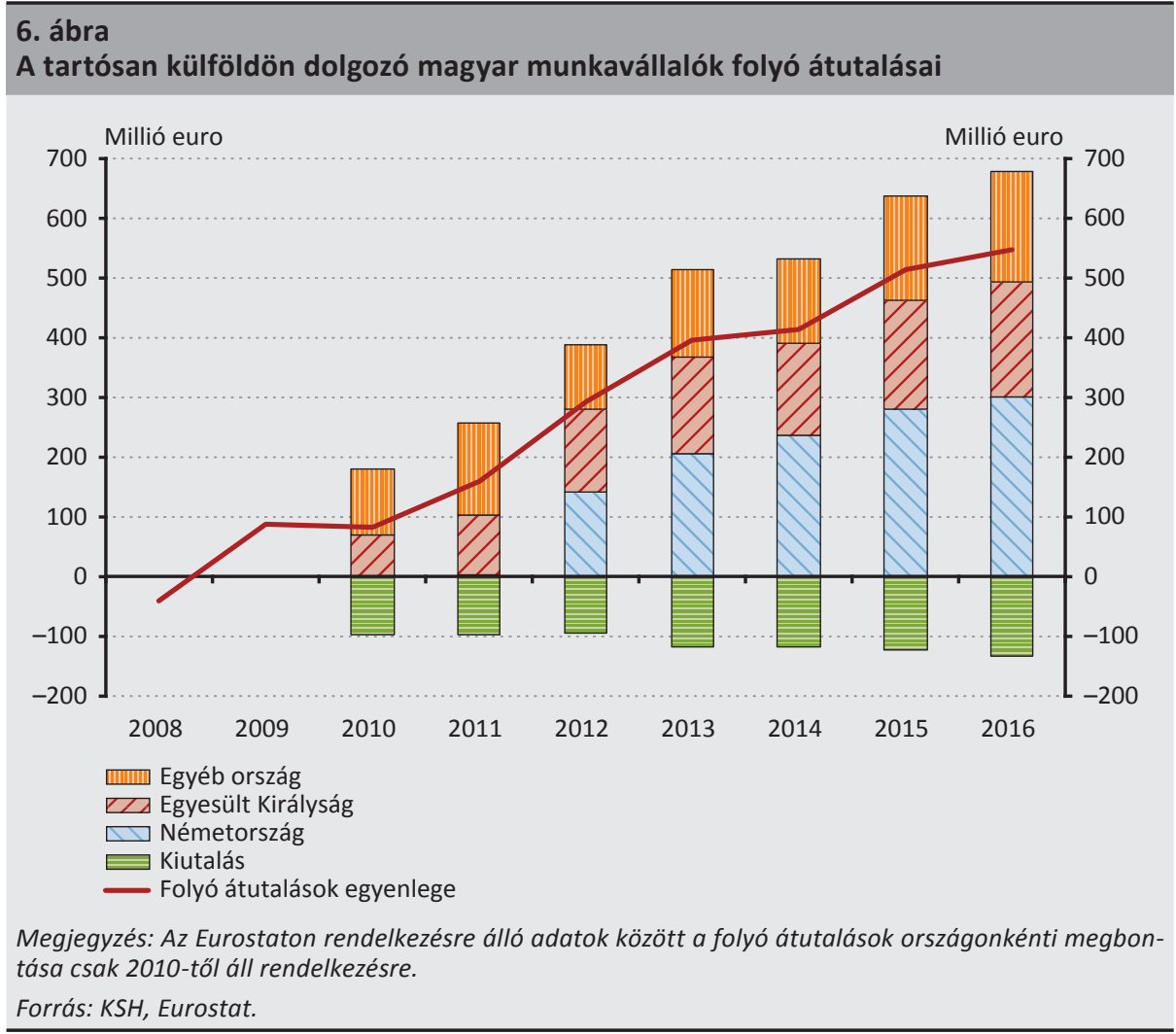


átutalások 2012-es és 2013-as során jelentősen bővültek, amelynek hátterében főként a Németországból származó átutalások emelkedése áll - ennek eredményeként a folyó átutalások 2013 és 2014 során már meghaladták az addig legjelentősebbnek tekinthető Egyesült Királyságból származó összeget. A Németországból érkező folyó átutalások 2016-ban mintegy 300 millió eurót tettek ki, míg a második legfontosabb Egyesült Királyságból mintegy 200 millió eurót. Az átutalások nagyságában utánuk következő néhány országból további 15-20 millió euro közötti összeget utalnak haza (ilyen ország pl. Svédország, Írország, Spanyolország, Olaszország, Hollandia, Szlovákia, valamint Belgium), míg a többi EU-s országból kevesebb hazautalás érkezik. A Magyarországon tartósan dolgozó külföldiek hazautalásait tekintve a legnagyobb értéket a Németországba irányuló utalások teszik ki, azonban itt számottevőnek mondható az Unión kívüli országokba utalt pénzek értéke is.

\section{A hazautalások nemzetközi összehasonlításban}

A külföldi munkavállalók jövedelmeinek és átutalásainak vizsgálata nem új keletü téma, és az elmúlt időszakban egyre nagyobb figyelem terelődik rá. Ennek hátterében egyrészt a külföldi munkavállalók jövedelmeinek és átutalásainak egyre növekvő mértéke áll, ami különösen a fejlődő országokra jellemző. A Világbank szerint a fejlődő (low and middle income countries) országokba irányuló külföldi munkavállalói jövedelmek és átutalások összege 2015-ben több mint 420 milliárd dollárt tett ki, és így a közvetlentőke-befektetések mellett jelentős külső finanszírozásnak tekinthető (7. ábra). Ezzel összhangban bizonyos országokban a külföldi munkavállalói jövedelmek és átutalások mértéke háromszor akkora összeget is kitehetnek, mint a hivatalos fejlesztési források, így érdemi hatással bírhatnak a társadalmi jólétre és a gazdasági fejlődésre. Emellett a hazautalások a közvetlentőke-befektetésekhez (FDI) és portfólió befektetésekhez képest stabilabb forrásnak számítanak, amelyet az adatok 2009-es alakulása is mutat. Míg a közvetlentőke-befektetések beáramlása egy év alatt mintegy harmadával estek vissza, addig a hazautalások mindössze 5 százalékkal csökkentek. A külföldi munkavállalói jövedelmek és átutalások összegét tekintve a Világbank adatai azt mutatják, hogy azok több mint 20 százaléka az Egyesült Államokból indul (főleg Mexikóba, Kínába és Indiába), amelyet Szaúd-Arábia, az Egyesült Arab Emírségek és az Egyesült Királyság követ. A legnagyobb összeget fogadó országok között pedig Indiát, Kínát és a Fülöp-szigeteket érdemes kiemelni, ahova a globális külföldi munkavállalói jövedelmek és átutalások közel 30 százaléka érkezik. 


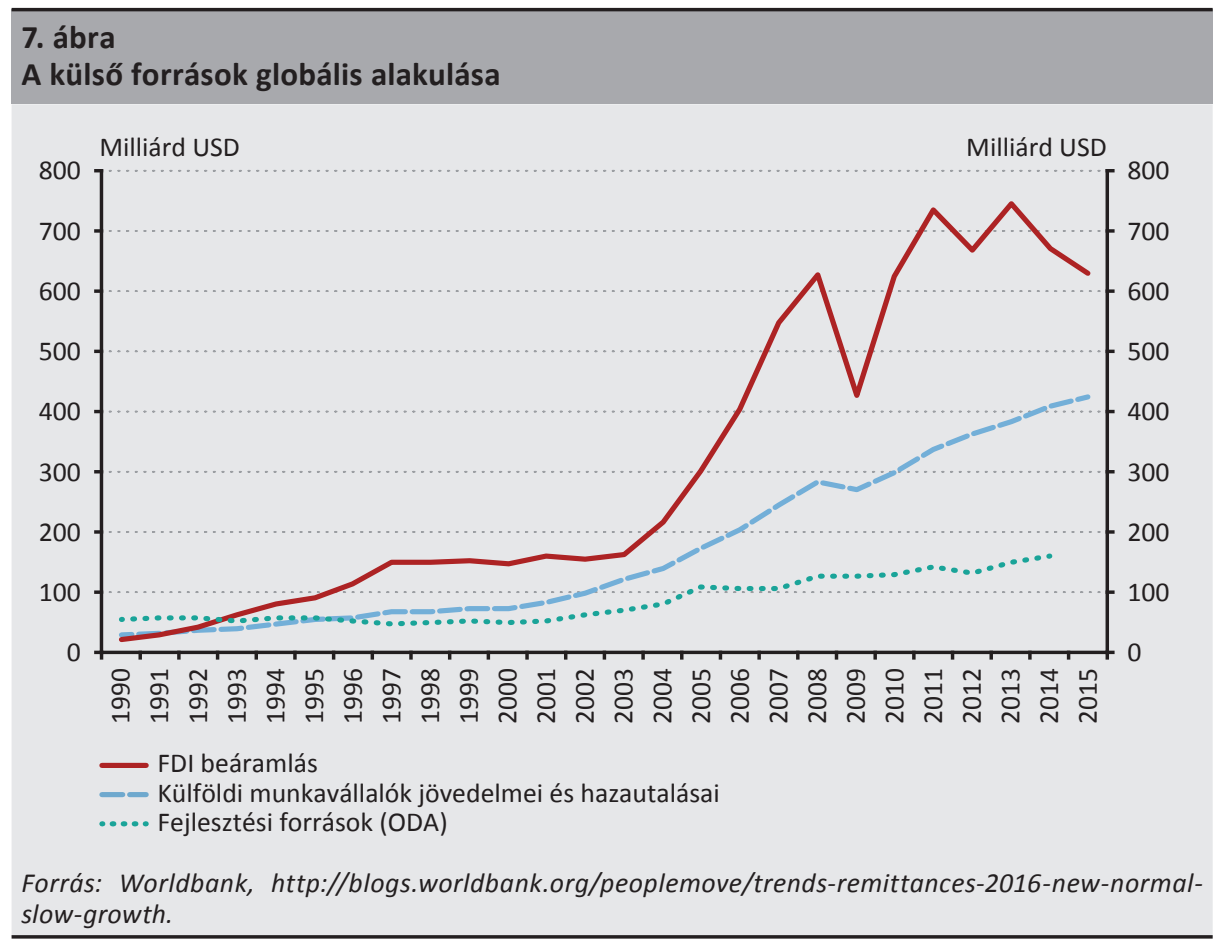

Az uniós országok között az átmenetileg külföldön dolgozó magyar munkavállalók GDP-arányos bérei a legnagyobbak, míg a folyó átutalások nem mondhatók kiugrónak (8. ábra). Az Unió országait összehasonlítva elmondható, hogy a külföldön átmenetileg munkát vállalók munkabére Magyarországon meghaladja az Unió többi országában megfigyeltet. Ezzel kapcsolatban érdemes szem előtt tartani - amit korábban is jeleztük -, hogy annak egy részét az adók és a megélhetési költségek fedezése teszi ki, így a munkajövedelemnek nem a teljes értéke növeli a fizetési mérleg többletét (ennek pontos értékét ugyanakkor nem ismerjük). A tartósan külföldön dolgozók átutalásait tekintve a GDP 0,6 százalékát kitevő érték nem mondható kirívónak európai összehasonlításban. A folyó átutalások mértéke a régió több országában is hasonló mértékű, vagy akár meg is haladja a Magyarországon megfigyelt értéket. Érdemes megjegyezni azt is, hogy az országok geográfiai elhelyezkedése is szerepet játszhat az átmeneti külföldi munkavállalásból származó bevételek alakulásában. Mint azt korábban láttuk, Magyarország számára ebből a szempontból a legfontosabb országnak Ausztria és Németország tekinthetó, amelyek közel helyezkednek el hazánkhoz. Érdemes ugyanakkor megnézni például Görögország adatát: az átmeneti külföldi munkavállalásból származó bérek értéke itt elenyésző, ami összefüggésben állhat azzal is, hogy Görögországnak nincs másik uniós szárazföldi szomszédja Bulgárián kívül. 


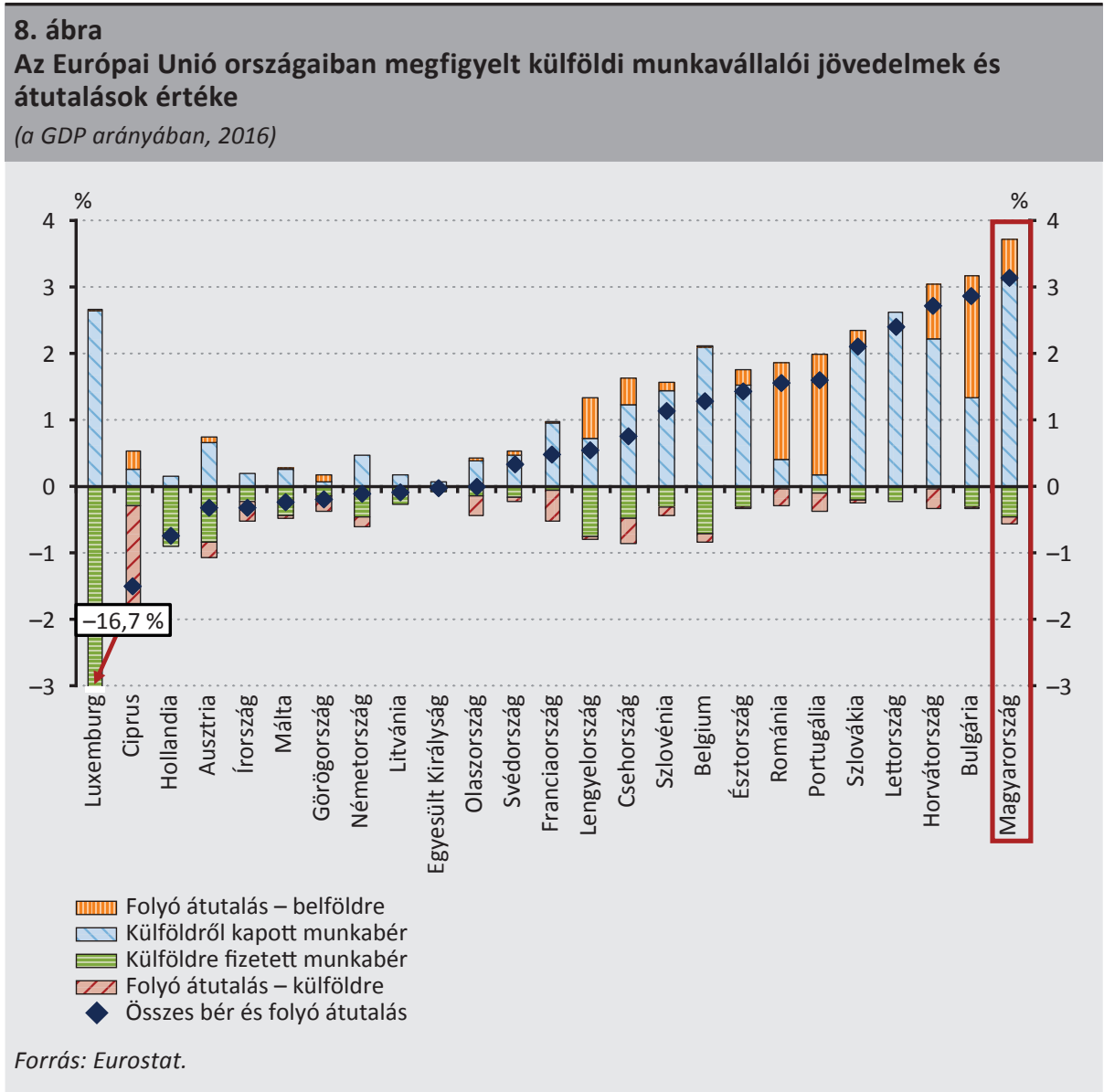

A külföldi munkavállalói jövedelmek és átutalások értéke az egy före jutó GDP emelkedésével arányosan mérséklödik az Unió országaiban, ami a fejlettséggel növekvő munkabérekkel áll összefüggésben (9. ábra). A külföldi munkabéreket és átutalásokat a gazdasági fejlettséget mutató egy före jutó GDP mutatóval összevetve az látható, hogy a fejlettebb országokba jóval kevesebb pénzt utalnak haza külföldröl, míg - főként az Európai Unióhoz 2004-ben és azt követően csatlakozott országokban - a külföldi munkavállalói jövedelmek és átutalások mértéke jóval magasabb. Ezzel párhuzamosan az is megfigyelhető, hogy a magasabb egy főre jutó GDP-vel rendelkező országokban általában a külföldi munkavállalói jövedelmek és átutalások kisebb mértéket öltenek. Ez arra vezethető vissza, hogy a külföldi munkavállalás egyik fő motivációja a magasabb munkabér elérése lehet. Így a magasabb egy före eső GDP-vel rendelkező országokba több külföldi munkavállaló érkezik, mint ahány azt az adott országot elhagyja. 


\section{9. ábra}

A külföldi munkavállalói bérek és folyó átutalások GDP-arányos értéke és a fejlettség kapcsolata

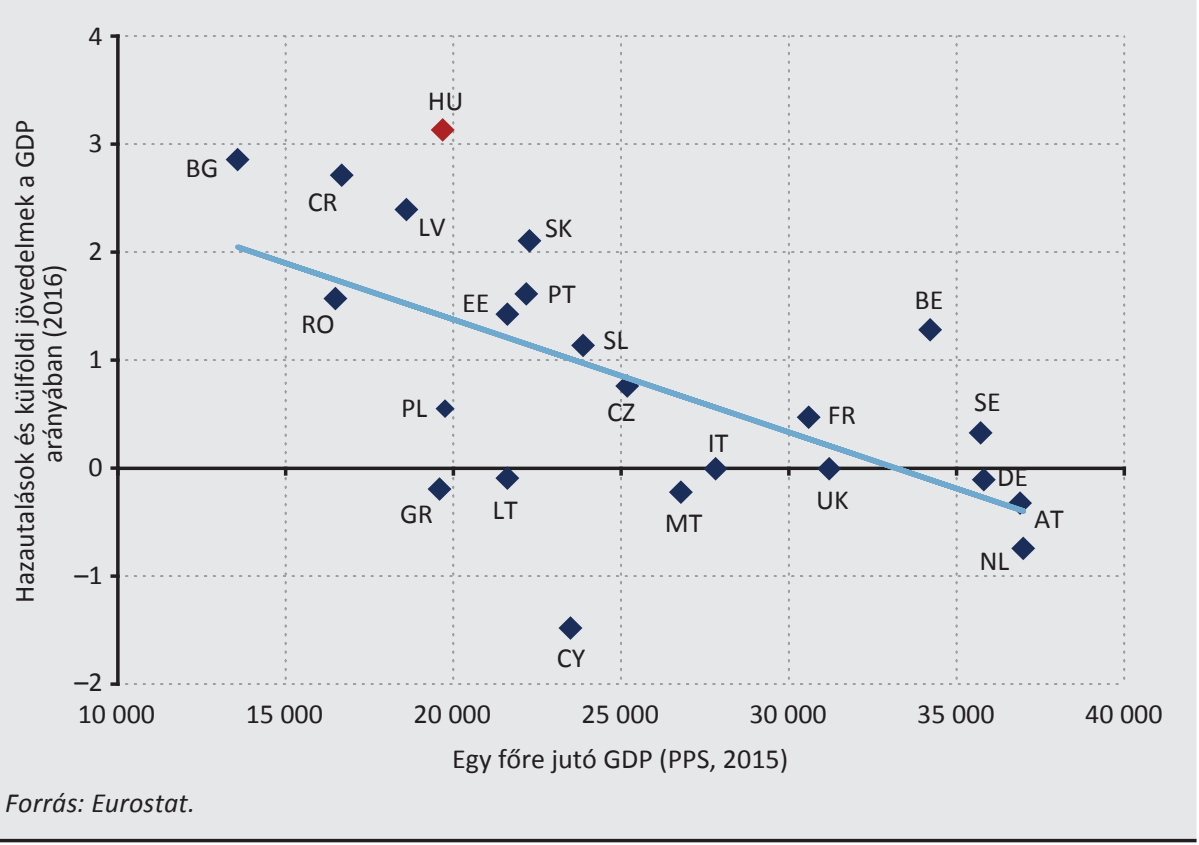

\section{6. Összefoglalás}

Összefoglalásként elmondható, hogy célszerű különbséget tenni az átmenetileg külföldön élő munkavállalók munkajövedelmének és a tartósan külföldön élők átutalásainak összege és a hazautalások között, ugyanis az első két tétel összege tartalmaz olyan tételeket is (pl. adók, megélhetési költségek), amelyek nem kerülnek ténylegesen hazautalásra. A hazautalásokhoz kapcsolódó fogalmak tisztázására és megértésére azért van szükség, mert azok más külső forrásoknál stabilabb külső finanszírozási forrást jelenthetnek egy gazdaság számára. Több szakirodalom szerint a külföldi munkavállalói jövedelmek és átutalások, illetve a hazautalások pozitív hatással lehetnek a gazdaságok növekedésére, amiben szerepet játszik a belső fogyasztás élénkítése; más szerzők szerint azonban ezeknek a tranzakcióknak negatív következményei is lehetnek, például a munkaerőpiaci hatásokon keresztül. A külföldi munkavállalói jövedelmek és átutalások a folyó fizetési mérleg egyenlegét javítják, ami kedvezően érintheti az adott ország befektetői megítélését is.

A magyar adatokat áttekintve az látható, hogy az átmenetileg külföldön dolgozók jövedelmének értéke jelentősen meghaladta a tartósan külföldön élők átutalásait. A külföldi munkavállalás szempontjából a magyar munkavállalók számára leg- 
fontosabb országoknak Németország és Ausztria mondható, ami a bérszínvonalak különbségéből, valamint földrajzi elhelyezkedésükből is adódik. A tartós külföldi munkavállalás és a folyó átutalások szempontjából szintén kiemelt jelentőséggel bír Németország, amit az Egyesült Királyság követ. Magyarországra főként a környező országokból (pl. Románia, Szlovákia) érkeznek munkavállalók, akik azonban nagyobb részben nem tartósan, inkább csak átmeneti jelleggel dolgoznak hazánkban. Az európai adatok alapján elmondható, hogy az Unió fejlettebb (mag)országaiba kevesebb külföldi munkavállalói jövedelem és átutalás érkezik, míg az Unióhoz 2004-ben vagy azt követően csatlakozó országokban a külföldi munkavállalás és a hazautalások mértéke érdemi.

\section{Felhasznált irodalom}

Adams, R. H., Jr. (1991): The Effects of International Remittances on Poverty, Inequality and Development in Rural Egypt. Research Report No. 96, International Food Policy Research Institute.

Aggarwal, R. - Demirgüc-Kunt, A. - Peria, M. S. M. (2006): Do Workers' Remittances Promote Financial Development? World Bank Policy Research Working Paper No 3957, the WB Group, Washington, D. C.

Ahlburg, D. A. (1996): Remittances and the Income Distribution in Tonga. Population Research and Policy Review, Vol. 15(4): 391-400. https://doi.org/10.1007/BF00128431.

Alper, A.M. - Neyapti, B. (2006): Determinants of workers' remittances: Turkish evidence from high frequency data. Eastern European Economics, 44(5): 91-100. https://doi. org/10.2753/EEE0012-8775440504.

Alvarez-Tinajera, S.P. (2010): Angola: A study of the impact of remittances from Portugal and South Africa. Migration Research Series, No 39, IOM, Geneva.

Barajasa, A. - Chami, R. - Hakura, D. - Montiel, P.J. (2011): Workers' remittances and the equilibrium real exchange rate: Theory and Evidence. Economia, 11: 45-94. https://doi. org/10.1353/eco.2011.0000.

Bodnár Katalin - Szabó Lajos Tamás (2014): A kivándorlás hatása a hazai munkaerőpiacra. MNB-tanulmányok 114.

Bourdet, Y. - Falck, H. (2006): Emigrants' remittances and Dutch disease in Cape Verde. International Economic Journal, 20(3): 267-84. https://doi. org/10.1080/10168730600879323.

Buch, C. - Kuckulenz, A. - Le Manchec, M. (2002): Worker Remittances and Capital Flows. Kiel Working Paper No., 1130, Kiel Institute for World Economics, Kiel. 
Buch, C. - Kuckulenz, A. (2004): Worker Remittances and Capital Flows to Developing Countries. Centre for Europena Economic Research (ZEW) Discussion Paper No. 04 31, ZEW, Mannheim.

Buch, C. M. - Kuckulenz, A. (2010): Worker Remittances and Capital Flows to Developing Countries. International Migration, 48(5): 89-117. https://doi.org/10.1111/j.14682435.2009.00543.x.

Bugamelli, M. - Paternó, F. (2009): Do Workers' Remittances Reduce the Probability of Current Account Reversals? World Development, 37(1): 81-92. https://doi.org/10.1016/j. worlddev.2009.04.002.

Chami, R. - Fullenkamp, C. - Jahjah, S. (2003): Are immigrant Remittance Flows a Source of Capital for Development? IMF Working Papers 03/189, International Monetary Fund, Washington, D. C.

Chami et al. (2008): Macroeconomic Consequences of Remittances. IMF Occasional Paper, 259, International Monetary Fund, Washington.

El-Sakka, M.I.T. - McNabb, R. (1999): The Macroeconomic Determinants of Emigrant Remittances. World Development, 27(8): 1493-1502. https://doi.org/10.1016/S0305750X(99)00067-4.

European Parliament (2014): The impacts of remittances on developing countries. http:// www.europarl.europa.eu/RegData/etudes/etudes/join/2014/433786/EXPO-DEVE_ ET(2014)433786_EN.pdf

De Haas, H. (2007): Remittances, migration and social development. A conceptual review of the literature. UNRISD Programme on Social Policy and Development Paper, No 34, Geneva.

Giuliano, P. - Ruiz-Arranz, M. (2005): Remittances, Financial Development, and Growth. IMF Working Paper 05/234. International Monetary Fund, Washington.

Giuliano, P. - Ruiz-Arranz, M. (2009): Remittances, financial development and growth. Journal of Development Economics, 90(1): 144-152. https://doi.org/10.1016/j. jdeveco.2008.10.005.

Gupta, S. - Pattillo, C. - Wagh, S. (2009): Impact of Remittances on Poverty and Financial Development in Sub-Saharan Africa. International Monetary Fund.

Glytsos, N. P. (1993): Measuring the Income Effects of Migrant Remittances: A Methodological Approach Applied to Greece. Economic Development and Cultural Change, Vol. 42(1): 131-168. https://doi.org/10.1086/452068. 
Hassan, G. - Holmes, M. (2015): Do Remittances Facilitate a Sustainable Current Account? The World Economy.

Holmes, M. J. (2006): How sustainable are OECD Current Account Balances in the Long-run? Manchester School, 74(5): 626-643. https://doi.org/10.1111/j.1467-9957.2006.00514.x.

IMF (2005): World Economic Outlook: Globalization and External Imbalances. Washington, D.C.: IMF.

IMF (2009): Balance of payment and international investment position manual 6th edition. IMF. https://www.imf.org/external/pubs/ft/bop/2007/pdf/bpm6.pdf.

IMF (2016): Emigration and Its Economic Impact on Eastern Europe. IMF Staff Discussion Note, July 2016. https://www.imf.org/external/pubs/ft/sdn/2016/sdn1607.pdf.

Kajdi László (2015): Hazautalt pénzek - nemzetközi áttekintés és a föbb mérési nehézségek. Statisztikai Szemle 93. évfolyam 4. szám: 353-375.

Kapur, D. (2004): Remittances: The New Development Mantra? United Nations Conference on Trade and Development, Geneva.

Lakatos Judit (2015): Külföldön dolgozó magyarok, Magyarországon dolgozó külföldiek. Statisztikai Szemle, 93. évfolyam, 2. szám: 93-112.

Léon-Ledesma, M. - Piracha, M. (2001): International Migration and the Role of Remittances in Eastern Europe. Studies in Economics, No. 0113, Department of Economics, University of Kent.

Levitt, P. (1998): Social remittances: Migration driven local-level forums of cultural diffusion. International Migration Review, 32(4): 926-948. https://doi.org/10.2307/2547666.

Lowell, B. L. - de la Garza, R. O. (2002): A new phase in the story of remittances. In: Sending Money Home: Hispanic Remittances and Community Development (R. De la Garza and B. L. Lowell, eds.). Rowmann and Littlefield Publishers, pp. 3-27)

MNB (2014): Magyarország fizetésimérleg és külfölddel szembeni befektetésipozíció-statisztikái. https://www.mnb.hu/letoltes/magyarorszagfizetesimerlegeskulfolddelszembenibefektetespoziciostatisztikai2014.pdf, letöltés ideje: 2016. november 15.

Nayyar, D. (1994): Migration, Remittances and Capital Flows: The Indian Experience. Oxford University Press, Delhi.

OECD (2006): International Migrant Remittances and their Role in Development. International Migration Outlook, Part III. https://www.oecd.org/els/mig/38840502.pdf. 
Orozco, M. et al. (2005): Transnational Engagement, Remittances and Their Relationship to Development in Latin America and the Caribbean. Institute for the Study of International Migration, Georgetown University.

Ratha, D. (2003): Workers' remittances: An important and stable source of external development finance. Global Development Finance. World Bank, Washington, D. C.

Ratha, D. - Mohapatra, S. - Silval, A. (2009): Outlook for Remittance Flows 2009-2011: Remittances Expected to Fall by 7-10 Percent in 2009 (Washington, DC: Migration and Development Brief, World Bank).

Ratha, D. (2013): The Impact of Remittances on Economic Growth and Poverty Reduction. Migration Policy Institute, Washington, D. C.

Solimano, A. (2003): Workers Remittances to the Andean Region: Mechanism, Costs, and Development Impact. Multilateral Investment Fund-IDB Conference, Remittances and Development, Quito, Ecuador.

Stark, O. - Taylor, J. E. - Yitzhaki, S. (1988): Migration, remittances and inequality: A sensitivity analysis using the extended Gini index. Journal of Development Economics, 28(3): 309-322. https://doi.org/10.1016/0304-3878(88)90002-8.

Stepanyan, V. - Poghosyan, T. - Bibolov, A. (2010): House Price Determinants in Selected Countries of the Former Soviet Union. IMF Working Paper 10/104, International Monetary Fund, Washington.

Stratan, A. et al. (2013): Development and side effects of remittances in the CIS countries: the case of Republic of Moldova. CARIM-East RR 2013/25, Robert Schuman Centre for Advanced Studies, European University Institute, San Domenico di Fiesola (FI).

Taylor, J. E. (1999): The New Economics of Labour Migration and the Role of Remittances in the Migration Process. International Migration, Vol. 37(1): 63-88. https://doi. org/10.1111/1468-2435.00066.

World Bank (2006): The Development Impact of Workers' Remittances in Latin America. Vol. II: Detailed Findings. The World Bank Group, Washington, D. C.

World Bank (2011): Migration, Remittances, and Development in Africa. World Bank, Washington D.C.

Yasseen, S. H. (2012): The positive and negative impact of remittances on economic growth in MENA countries. The Journal of International Management Studies, 7(1), April. 